\title{
Treatment of Bartter's syndrome in early childhood with prostaglandin synthetase inhibitors
}

\author{
J. M. LITTLEWOOD, M. R. LEE, AND S. R. MEADOW \\ From the Department of Paediatrics, Seacroft Hospital, Leeds, and Department of Medicine, Leeds General \\ Infirmary
}

SUMmaRY The diagnosis of Bartter's syndrome was made in a 9-month-old boy investigated for poor weight and height gain. Initial treatment with oral potassium supplements and later spironolactone had little or no effect on his growth, although plasma potassium rose to normal after spironolactone. At 33 months indomethacin therapy was started with dramatic results. His symptoms went and his height and weight accelerated into the normal range. In view of the toxicity of indomethacin it was replaced after 12 months by another prostaglandin synthetase inhibitor, ketoprofen, with a satisfactory result. During the change-over period from indomethacin to ketoprofen the expected deterioration in clinical well-being was observed, accompanied by a rise in urinary prostaglandins and plasma renin activity. Prostaglandin synthetase inhibitors provide the best available treatment for Bartter's syndrome.

In 1962 Bartter and colleagues described a syndrome of hypokalaemia, alkalosis, raised plasma renin activity, and hypertrophy of the juxtaglomerular apparatus but without hypertension. In children there is associated growth failure (Bryan et al., 1966). Several groups of investigations had suggested that there was an obligate loss of sodium in the urine of patients with this disorder (Cannon et al., 1968; Lee, 1969). It had also been proposed that there could be an inappropriate production of renin and on this basis beta-adrenergic blocking agents, such as propanolol, had been tried (Modlinger et al., 1973).

In 1975 Belgian workers (Verberckmoes et al., 1976) observed hyperplasia of the renomedullary interstitial cells in Bartter's syndrome. In view of the suggested association of these cells with prostaglandin production (Muirhead et al., 1972), they administered a known inhibitor of prostaglandin synthetase (indomethacin) to an adult patient with this disorder. The initial results were excellent and this finding has been confirmed by others in the United States (Fichman et al., 1976; Gill et al., 1976).

We report here the diagnosis of Bartter's syndrome in an infant and its successful treatment with indomethacin. The long-term use of this drug presents certain difficulties. There is a substantial incidence of gastric erosions and also serious side effects within the central nervous system including headache and

Received 9 June 1977 hallucinations. We therefore changed his therapy to ketoprofen, a known prostaglandin synthetase inhibitor, with fewer reported side effects (Fossgreen et al., 1975). During the change-over period detailed study was made of clinical and biochemical changes.

\section{Methods}

Plasma renin activity was determined by a modification of the method of Ryan et al. (1968). The angiotensinase inhibitors were dimercaprol; 8hydroxyquinoline; phenylmethylsulphonylfluoride; and ethylenediaminetetraacetic acid. The angiotensin I formed was determined by radioimmunoassay and the bound and free separated by dextran-coated charcoal.

Urinary prostaglandins were measured by $\mathrm{Dr}$ Frank Burnet, John Radcliffe Hospital, Oxford. They were determined by radioimmunoassay after separation by column chromatography. Results are expressed in terms of $\mathrm{ng}$ equivalents of $\mathrm{PGE}_{2}$ or $\mathrm{PGF}_{2} \alpha$.

Plasma aldosterone was measured by radioimmunoassay after chromatography on LH20 columns. The antiserum, raised to aldosterone conjugated through C3, was kindly supplied by Professor V. H. T. James, St Mary's Hospital Medical School, London. Other investigations were carried out by standard laboratory methods. 


\section{Case report}

A Caucasian boy of 4 years had presented at age 9 months because of poor weight gain. $\mathrm{He}$ is the second child of healthy parents and there is an older sister aged 6 years who is well. Both parents and the sister have normal plasma electrolytes. Pregnancy was uneventful and delivery at 39 weeks' gestation was normal; birthweight was $3650 \mathrm{~g}$. He was slow to gain weight during the first 2 weeks, after which he appeared to progress normally. However, his weight of $5 \mathrm{~kg}$ at 3 months was just below the 25 th centile and his weight of $6.8 \mathrm{~kg}$ at 7 months was only on the 3 rd centile. He was breast fed for $4 \frac{1}{2}$ months and thereafter fed on cows' milk. Cereals and mixed foods had been added at $3 \frac{1}{2}$ months, and from then on he was a 'difficult feeder'. There had been frequent small vomits from birth until the age of 8 months. He tended to be constipated during the early weeks of life passing hard stools every 2 to 3 days.

When first seen at age 9 months he weighed 6.75 $\mathrm{kg}$ ( $1 \mathrm{~kg}$ below $3 \mathrm{rd}$ centile) and was $70.5 \mathrm{~cm}$ long (50th centile). He was pale and very thin; the ears were slightly prominent; his eyes were blue but there was a small brown quadrant in the right iris; the wasting was of both subcutaneous tissue and muscles, and the latter were markedly hypotonic. The cardiovascular system was normal; blood pressure 100/55 $\mathrm{mmHg}$ with a $7 \mathrm{~cm}$ cuff. Small hard faecal masses were palpable in the abdomen. General developmental progress was thought to be within normal limits for age. Urine examination was negative for glucose, total reducing substances, albumin, and blood. $\mathrm{pH}$ was $7 \cdot 0$.

Investigations. Plasma electrolytes at 9 months: $\mathrm{K} 2 \cdot 4, \mathrm{Na} 131$, bicarbonate 30 , urea $5 \cdot 8 \mathrm{mmol} / 1$ $(34.9 \mathrm{mg} / 100 \mathrm{ml})$. Urine electrolytes: $\mathrm{K} 87, \mathrm{Na} 85$, and $\mathrm{Cl} 81 \mathrm{mmol} / \mathrm{l}$. Blood $\mathrm{pH}$ was $7 \cdot 59, \mathrm{PCO}_{2} 4 \cdot 6 \mathrm{kPa}$ (33 $\mathrm{mmHg}$ ), and base excess $10 \cdot 1 \mathrm{mmol} / \mathrm{l}$. Two determinations of plasma renin activity showed levels of 23100 and $27800 \mathrm{pg} / \mathrm{ml}$ per hour (Dr M. Dillon: normal $50-500 \mathrm{pg} / \mathrm{ml}$ per hour). Plasma aldosterone was $36 \mathrm{ng} / 100 \mathrm{ml}(0.999 \mathrm{nmol} / \mathrm{l})$ (normal) and urinary aldosterone was $15 \mu \mathrm{g} / 24$ hours (high normal). Hb was $11.5 \mathrm{~g} / \mathrm{dl}(79 \%)$, and white blood count $11.5 \times 10^{9} / 1$. Differential white blood count and blood film were normal.

Other investigations were calcium $2.5 \mathrm{mmol} / 1$ (10 $\mathrm{mg} / 100 \mathrm{ml})$, phosphorus $1.5 \mathrm{mmol} / 1$ (4.64 $\mathrm{mg} / 100 \mathrm{ml})$, serum cholesterol $4.8 \mathrm{mmol} / 1$ (185 $\mathrm{mg} / 100 \mathrm{ml})$, triglyceride $2 \cdot 0 \mathrm{mmol} / 1(177 \mathrm{mg} / 100 \mathrm{ml})$. Alkaline phosphatase $35.5 \mathrm{King}$-Armstrong units/ $100 \mathrm{ml}$. Magnesium $0.8 \mathrm{mmol} / 1(1.95 \mathrm{mg} / 100 \mathrm{ml})$. Urinary oxosteroids (ketosteroids) $3.0 \mu \mathrm{mol}(0.86$ $\mathrm{mg}$ ) per 24 hours; 17-oxogenic steroids (hydroxy- corticosteroids) $5.9 \mu \mathrm{mol}(1.7 \mathrm{mg})$ per 24 hours. Urine culture and microscopy were negative. Whole body potassium (age 14 months) showed a total $\mathrm{K}$ content of $412 \mathrm{mmol}$, equivalent to $51 \cdot 2 \mathrm{mmol} / \mathrm{kg}$ body weight (normal). $X$-rays of the chest and abdomen were normal and wrist $x$-ray showed a bone age of 9 months (Greulich and Pyle method). Intravenous pyelogram: left kidney $9.0 \mathrm{~cm}$ and right kidney $8 \cdot 8 \mathrm{~cm}$ (1 SD above the mean for a height of $71 \mathrm{~cm}$ ). The kidneys, ureters, and bladder were normal. Barium swallow was normal. Electrocardiogram showed changes compatible with mild hypokalaemia. Sweat test: $\mathrm{Na} 22 \mathrm{mmol} / 1, \mathrm{Cl} 9 \mathrm{mmol} / 1$.

Treatment and progress. The diagnosis was suggested on the first electrolyte results and confirmed by the markedly raised renin levels in the presence of a normal blood pressure. Treatment was started at 11 months by increasing the dietary intake of potassium. The addition of $\mathrm{K}$ supplements to a total of approximately $80 \mathrm{mmol} /$ day caused an encouraging but transient weight gain but had no effect on plasma $K$ levels. Spironolactone $(18.75 \mathrm{mg} /$ day $)$ was added at 18 months and although plasma $\mathrm{K}$ returned to low normal levels, there was no effect on his poor growth and weight gain. Magnesium supplements were added at the age of 2 years 2 months, without obvious clinical or biochemical benefit.

At 2 years 4 months $\mathrm{Na}$ intake was increased by the addition of $3.0 \mathrm{~g} \mathrm{NaCl}$ per day. Although this was followed by an increase in the thirst which had been noted as a clinical feature during the second year, there was a definite increase in activity and well-being but no improvement in his growth, either in rate of weight or height gain. The added sodium was therefore discontinued.

At 2 years 9 months indomethacin therapy was added to the increased dietary $\mathrm{K}(80 \mathrm{mmol} / \mathrm{day})$ and the spironolactone $(18 \cdot 75 \mathrm{mg} /$ day $)$. The effect on symptoms and growth was dramatic. Within 2 days thirst and polyuria stopped and the constipation improved. There was a marked increase in appetite and general well-being. Improved growth was evident on the growth chart and coincided with the start of indomethacin (Fig. 1), which was started in small doses of $2.5 \mathrm{mg}$ tds and gradually increased to $7 \cdot 5 \mathrm{mg}, 5 \mathrm{mg}, 7 \cdot 5 \mathrm{mg}$ daily over a 4-week period. Plasma $\mathrm{K}$ failed to return to normal levels but $\mathrm{Na}$ returned to normal for the first time after life-long hyponatraemia.

Metabolic study. At age 3 years 9 months, after 12 months of indomethacin, therapy was changed to ketoprofen. A metabolic study lasting 15 days was carried out, comprising 8 days on indomethacin $20 \mathrm{mg}$ daily, 4 days off treatment, and 3 days on 


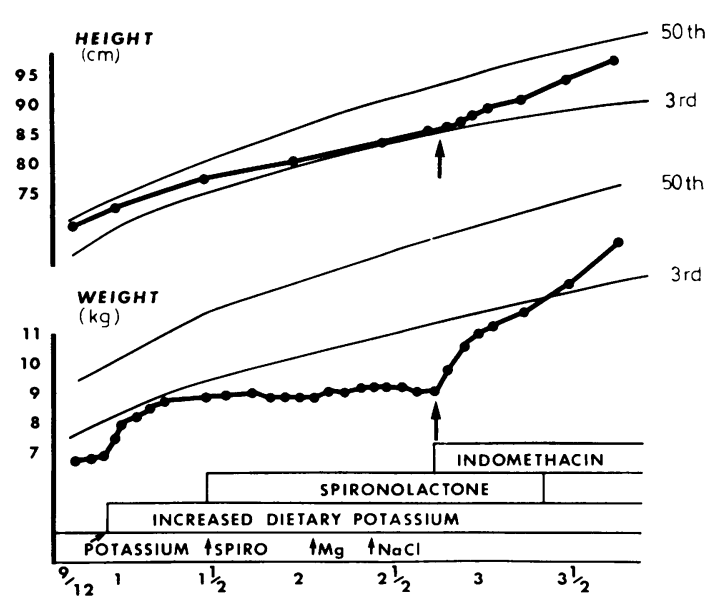

Fig. 1 Response of Bartter's syndrome to potassium, spironolactone, and indomethacin therapy.

ketoprofen $30 \mathrm{mg}$ daily (Fig. 2). The following observations were made. Daily 24-hour urines for volume; electrolytes; prostaglandins $\left(\mathrm{PGE}_{2}\right.$ equivalents and $\mathrm{PGF}_{2} \alpha$ equivalents); daily weight, blood pressure, $\mathrm{Na}$ and $\mathrm{K}$ intake: plasma electrolytes and urea were measured on days $3,4,5,7,8,9,10,11,12$, 13, 15: plasma aldosterone and renin activity were

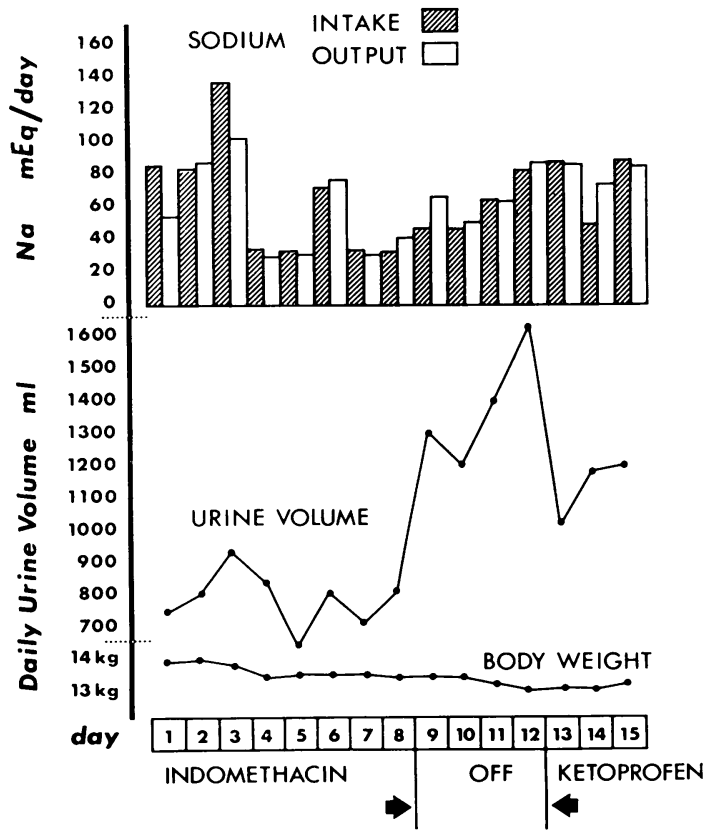

Fig. 2 Response of Bartter's syndrome to indomethacin and ketoprofen. measured on days $3,4,8,9,12,13,15$. On days 5,6 , and 7 of the study he had mild pharyngitis, was generally unwell and received treatment with oral penicillin.

In the 4-day period after indomethacin was stopped (days 9-12 inclusive), he was well but thirst increased from day 10 onwards. This was partially relieved after starting ketoprofen on day 13 , but not completely controlled for some 6 weeks by which time ketoprofen dosage had been gradually increased to $60 \mathrm{mg}$ daily.

The data derived from this metabolic study are given in the Table. Urine volume, $\mathrm{Na}$ intake and output, and body weight are shown in Fig. 2 and the marked increase in urinary output during the period off treatment is evident. The results of the measurement of urinary prostaglandins and plasma renin activities are given in the Table. Urinary prostaglandins increased approximately eightfold when indomethacin was stopped and fell when ketoprofen was started. The rise in plasma renin activity to $85 \mathrm{ng} / \mathrm{ml}$ per hour on the fourth day while on indomethacin was accounted for by a short period of illness due to a throat infection. No standards for children are available for the present method of measuring plasma renin activity and all the values are high by adult standards $(2-10 \mathrm{ng} / \mathrm{ml}$ per $\mathrm{h})$.

\section{Discussion}

As the clinical and biochemical features of this infant were so strongly suggestive of Bartter's syndrome renal biopsy was not warranted. The dramatic response to indomethacin and the structurally unrelated prostaglandin synthetase inhibitor, ketoprofen, confirm that the patient is producing prostaglandins in excess, supporting the presumptive diagnosis of Bartter's syndrome. As a result of treatment with indomethacin the child became to all intents and purposes normal, but his plasma potassium remained slightly low at $2.8 \mathrm{mmol} / 1$ despite potassium supplements and plasma renin activity remained raised. Both these findings may represent inadequate or uneven suppression of abnormal prostaglandin production.

Although it has been considered from animal studies that ketoprofen is equipotent with indomethacin, the initial response to $2 \cdot 3 \mathrm{mg} / \mathrm{kg}$ per day of ketoprofen was somewhat unsatisfactory and the dose was therefore raised to $4.6 \mathrm{mg} / \mathrm{kg}$ in divided doses. There have been no serious side effects from either drug. At the moment the response to treatment has to be judged on height and weight gain, the elimination of thirst and polyuria, and the plasma electrolytes. In future it may be possible to monitor therapy by regular determination of urinary prosta- 


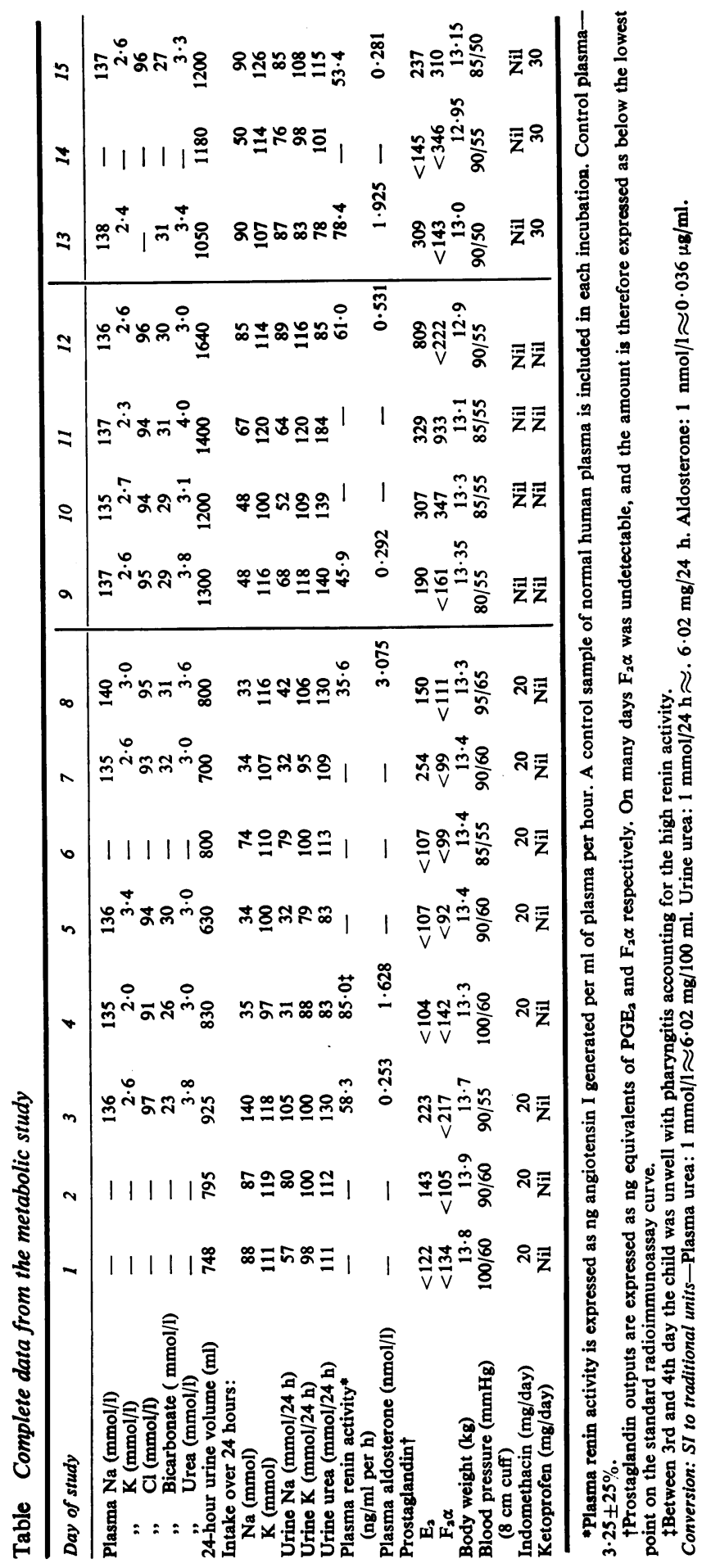


glandins and plasma renin activity but at the moment these techniques depend on difficult radioimmunoassays which are not generally available.

The nature of the prostaglandin abnormality in Bartter's syndrome remains controversial. Gill et al. (1976) measured urinary prostaglandin $E_{2}$ and $F_{2} \alpha$ in several patients with the disorder and suggested that there was an increase in the urinary excretion of prostaglandin $\mathrm{E}_{2}$ but that changes in $\mathrm{F}_{2} \alpha$ were less remarkable. In their hands, treatment with indomethacin (100-200 mg/day) decreased urinary prostaglandin $\mathrm{E}_{2}$-like material by $69 \%$. Plasma renin activity and urinary aldosterone fell substantially on the anti-inflammatory drug. Our urinary prostaglandin results suggest that when therapy with indomethacin was stopped, prostaglandin $\mathrm{E}_{2}$ increased fivefold (as did $F_{2} \alpha$ ). However, the peak of prostaglandin $\mathrm{E}_{2}$ excretion corresponded more closely with the duration of relapse, whereas the excretion of $\mathrm{F}_{2} \alpha$ had begun to fall before ketoprofen therapy was started. Another major prostaglandin produced by the renal medulla is prostaglandin $\mathbf{A}_{2}$ and this has been shown to be increased in the urine of patients with Bartter's syndrome by Fichman et al. (1976). Muirhead et al. (1972) have also shown that tissue cultures of renomedullary interstitial cells can convert arachidonic acid to the three prostaglandins, $A_{2}, E_{2}$, and $F_{2} \alpha$.

It has been suggested that the balance between vasoconstriction and vasodilatation in the kidney, and the resulting changes in sodium handling is determined not by the absolute amount of prostaglandin synthetase produced by the renal tissue but by the ratio between prostaglandin $E_{1}$ and $E_{2}$. Thus, if prostaglandin $E_{2}$ were vasodilator and natriuretic then $E_{1}$ would be vasoconstrictor and sodium retaining (Armstrong et al., 1976). It is theoretically possible that the ratio of prostaglandin $E_{1}$ to $E_{2}$ could be manipulated artificially, increasing $E_{2}$ by dietary administration of arachiodonic acid or, alternatively, $\mathrm{E}_{1}$ by the administration of dihomogammalinolenic acid (Willis et al., 1974).

Until recently the diagnosis of this rare disorder was a matter of academic interest as there was no effective treatment. The patients often remained small, had serious symptoms referable to their low plasma potassium, and some died as a result of chronic renal failure (Lancet, 1976). The advent of specific therapy directed towards a long-term amelioration of the clinical syndrome makes the early diagnosis and treatment of this disorder imperative. There is now the expectation that many of these children will survive into adult life and avoid the serious consequences of their metabolic disturbance, provided that they are treated with prostaglandin synthetase inhibitors.
We thank the parents for co-operation particularly during the metabolic study; Sisters. Moriarty and the nursing staff, Outpatient Department, Seacroft Hospital; Dr M. Dillon, The Hospital for Sick Children, for initial plasma aldosterone and renin determinations; Dr S. G. Ball, Department of Medicine, Leeds General Infirmary for later plasma renin determinations; Dr Frank Burnet, John Radcliffe Hospital, Oxford, for urinary prostaglandin measurements; Mrs M. Cawood and Dr M. J. Levell, Leeds Supraregional Assay Service for the later determinations of aldosterone; Dr L. Burkinshaw, Department of Medical Physics, Leeds General Infirmary, for total body potassium determinations; Mr A. E. Steel and Dr Angela Robinson for biochemical and haematological estimations; Mrs Susan Pattinson for dietary advice; Mrs Christine Silburn for secretarial assistance.

\section{References}

Armstrong, J. M., Blackwell, G. J., Flower, R. J., McGiff, J. C., Mullaine, K. M., and Vane, J. R. (1976). Genetic hypertension in rats is accompanied by a defect in renal prostaglandin catabolism. Nature, 260, 582-586.

Bartter, F. C., Pronove, P., Gill, J. R., and MacCardle, R. C. (1962). Hyperplasia of the juxtaglomerular complex with hyperaldosteronism and hypokalemic alkalosis. American Journal of Medicine, 33, 811-828.

Bryan, G. T., MacCardle, R. C., and Bartter, F. C. (1966). Hyperaldosteronism, hyperplasia of the juxtaglomerular complex, normal blood pressure and dwarfism: report of a case. Pediatrics, 37, 43-50.

Cannon, J., Leeming, J. M., Sommers, S. C., Winters, R. W., and Laragh, J. H. (1968). Juxtaglomerular cell hyperplasia and secondary hyperaldosteronism (Bartter's syndrome): a re-evaluation of the pathophysiology. Medicine, 47, 107-131.

Fichman, M. P., Telfer, N., Zia, P., Speckart, P., Golub, M., and Rude, R. (1976). Role of prostaglandins in the pathogenesis of Bartter's syndrome. American Journal of Medicine, 60, 785-797.

Fossgreen, J., Kirchkeiner, B., Peterson, O. E., Tophoj, E., and Zachariae, E. (1973). Clinical evaluation of ketoprofen (19583RP) in rheumatoid arthritis. Double blind crossover trial against indomethacin. 13th International Congress of Rheumatology, Kyoto. International Congress Series. Excerpta Medica, Amsterdam.

Gill, J. R., Frölich, J. C., Bowden, R. E., Taylor, A. A., Keiser, H. R., Seyberth, H. W., Oates, J. A., and Bartter, F. C. (1976). Bartter's syndrome: a disorder characterised by high urinary prostaglandins and a dependence of hyperreninemia on prostaglandin synthesis. American Journal of Medicine, 61, 43-51.

Lancet (1976). Bartter's syndrome, 2, 721-722.

Lee, M. R. (1969). Renin and Hypertension. A Modern Synthesis, p. 188 Lloyd-Luke, London.

Modlinger, R. S., Nicolis, G. L., Krakoff, L. R., and Gabrilove, J. L. (1973). Some observations on the pathogenesis of Bartter's syndrome. New England Journal of Medicine, 289, 1022-1024.

Muirhead, E. E., Germain, G., Leach, B. E., Pitcock, J. A., Stephenson, P., Brooks, B., Blosius, W. L., Daniels, E. G., and Hinman, J. W. (1972). Production of renomedullary 
prostaglandins by renomedullary interstitial cells grown in tissue cultures. Circulation Research, 30 and 31, Suppl. 2, 161-172.

Ryan, J. W., McKenzie, J. K., and Lee, M. R. (1968). A rapid, simple method for the assay of renin in rabbit plasma. Biochemical Journal, 108, 679-685.

Verberckmoes, R., Van Damme, B., Clement, J., Amery, A., and Michielsen, P. (1976). Bartter's syndrome with hyperplasia of renomedullary interstitial cells: successful treatment with indomethacin. Kidney International, 9, 302-307.

Willis, A. L., Comai, K., Kuhn, D. C., and Paulsrud, J. (1974). Dihomo $\gamma$ linolenate suppresses platelet aggregation in vitro or in vivo. Prostaglandins, 8, 509-519.

Correspondence to Dr J. M. Littlewood, Department of Paediatrics, Seacroft Hospital, Leeds LS14 6UH. 